\title{
Relation of measles virus to encephalitogenic factor with reference to the aetiopathogenesis of multiple sclerosis
}

\author{
J. R. McDERMOTT, E. J. FIELD, ${ }^{1}$ AND E. A. CASPARY \\ From the Medical Research Council Demyelinating Diseases Unit, Newcastle \\ General Hospital, Newcastle upon Tyne
}

SYNOPSIS A combination of affinity chromatography with the macrophage electrophoretic migration (MEM) test has been used to study the antigenic similarities between encephalitogenic factor (EF) and measles virus. These have determinant(s) sufficiently closely related to account for the elevated level of circulating antibody to measles in multiple sclerosis.

Recent years have seen more than 20 reports (reviewed by Brody, 1972) indicating that the level of measles antibody in blood is in general higher in patients with multiple sclerosis than in normal subjects. Since the association of measles with subacute sclerosing panencephalitis (SSPE) is now generally accepted, it has been suggested that measles virus might operate as a 'slow' agent in multiple sclerosis too. An alternative explanation of the elevated measles titre in multiple sclerosis (MS), is that breakdown products of nervous tissue (and notably encephalitogenic factor (EF)) may share antigenic determinant(s) with measles virus so that the cross reactivity of serum antibody to such breakdown products is interpreted as elevated measles titre. The present work offers direct evidence that measles virus and encephalitogenic factor (EF) do indeed share antigenic determinant(s).

\section{METHODS}

The method employed has been to estimate blood lymphocyte sensitization to measles and EF; to filter out lymphocytes with specific sensitization to either measles or EF by affinity chromatography and subsequent re-estimation of the sensitivity of the lymphocytes which have come through the chromatography column. In a typical experiment lympho-

1 Present address: Institute of Pathology, Newcastle General Hospital, Newcastle upon Tyne. cytes from a patient with MS were assayed for sensitization to EF and to measles. The cells were then passed down a column packed with Bio-Gel P-2 beads to which EF was linked so that lymphocytes sensitized to EF were retained. The cells issuing from the columns were re-estimated for sensitization both to EF and measles. In such an experiment the effluent cells, while showing the expected marked reduction in sensitization to $\mathrm{EF}$, also showed reduced sensitization to measles.

Lymphocytes were isolated from $15 \mathrm{ml}$. venous blood by the method of Coulson and Chalmers (1967) using methyl cellulose and carbonyl iron as modified by Hughes and Caspary (1970). More than $98 \%$ pure lymphocytes were obtained with almost $100 \%$ viability (as shown by an erythrosin exclusion test). Cells from eight patients with multiple sclerosis (seven in an acute episode; one quiescent); one patient with syringomyelia, and one with stroke; two children with measles; and two normal adults have been studied.

Lymphocyte sensitization was measured by the macrophage electrophoretic mobility (MEM) test (Field and Caspary, 1970, 1971; Caspary and Field, 1971). In principle the method depends upon the observation that, when sensitized lymphocytes are brought into the presence of antigen, they elaborate a 'lymphokine' (macrophage slowing factor-MSFwhich may be identical with MIF) with the property of causing normal guinea-pig macrophages to travel more slowly in an electric field. Normal macrophages may thus be used as an indicator system for the interaction of lymphocytes with antigen. A detailed 
description of the test together with an experimental protocol in extenso has been given by Field and Caspary (1971).

If $t_{c}=$ migration time of the macrophages when no antigen is present; $t_{e}=$ migration time when antigen present; then in general $t_{e}>t_{c}$ and $\left.t_{e}-t_{c} / t_{c}\right) \times 100$ is a measure of the slowing induced by the interaction of lymphocytes and antigen and so of lymphocyte sensitization. It is these percentage figures which are given in the protocols. All estimations were, of course, carried out 'blind'.

In carrying out a test for lymphocyte sensitization $0.5 \times 10^{6}$ lymphocytes are used as a routine. This number contains sufficient lymphocytes with specific sensitization to give a maximal response (Carnegie et al., 1973). By dropping the number of lymphocytes to $0.4,0.3, \ldots 0.05$ million it is possible to estimate the 'end point' at which there are not enough specifically sensitized cells present to give a significant result (Field and Caspary, 1972; Caspary and Field, 1974). This 'titration method' has been adopted for the lymphocytes before and after passage through specifically loaded columns.

The antigens used have been encephalitogenic factor (EF) made from normal human white matter (Caspary and Field, 1965); mevillin-L (Schwartz strain) measles (Evans Medical); control culture material in which the mevillin- $\mathrm{L}$ is produced (kindly supplied by Dr. Fermiger of Evans Medical Ltd.); $F_{1}$ (thyroglobulin) fraction of normal human thyroid; purified protein derivative (PPD) of $M$. tuberculosis; and calf thymus histone (Sigma chemicals).

In the case of EF, PPD, and thyroglobulin the antigen has been used at a concentration of $33 \mu \mathrm{g} / \mathrm{ml}$. in the MEM test. With mevillin-L $0 \cdot 1 \mathrm{ml}$. has been used in a final volume of $3 \cdot 1 \mathrm{ml}$.

Chromatography columns were prepared with Bio-Gel beads (50-100 mesh; Bio-Rad Labs., Richmond, Calif.) to which EF or other antigen had been coupled by the azide method of Inman and Dintzis (1969), to give a loading of approximately $2 \mathrm{mg}$ antigen/g dry resin. To reduce non-specific retention of lymphocytes the column was washed with $0.5 \mathrm{ml}$. normal serum followed by $5 \mathrm{ml}$. medium 199 (Wigzell and Andersson, 1969). The column was usually $1 \mathrm{~cm}$ high and $2 \cdot 1 \mathrm{~cm}$ diameter. Cells in medium 199 at $\mathrm{pH} 7 \cdot 2$ were layered on to the column at a concentration of $2.0 \times 10^{6} \mathrm{ml}$. and allowed to pass through under gravity at $20^{\circ} \mathrm{C}$ at a flow rate of $1.0 \mathrm{ml} . / \mathrm{min}$. Finally the column was washed with $5 \mathrm{ml}$. fresh medium 199 and the eluate and washings combined. Lymphocyte recovery varied between 75 and $98 \%$.

\section{RESULTS}

MULTIPLE SCLEROSIS LYMPHOCYTES 1. Normally, 0.5 million lymphocytes are used in a test for sensitization. It can be seen from Table 1 that when the number of cells is reduced a positive reaction to $\mathrm{EF}$ - that is, greater than $2.5 \%$; $\mathbf{P}<0.01$-is still obtained with $0.05 \mathrm{~m}$ cells but not with 0.01 . Passing the cells down a column of histone-Bio-Gel-that is, a non-specific basic protein-led to negligible retention of $\mathrm{EF}$ sensitized cells. An EF loaded column on the other hand removed so many cells that even $0 \cdot 3 \mathrm{~m}$ failed to give a positive result. This showed that an EF loaded Gio-Gel column retains significant numbers of lymphocytes which are sensitive to EF.

\section{TABLE 1}

CHRONIC MS LYMPHOCYTES; EF ANTIGEN: HISTONE-BIO-GEL AND EF-BIO-GEL COLUMNS

\begin{tabular}{cccccc}
\hline \multirow{2}{*}{$\begin{array}{c}\text { No. of cells } \\
\left(\times 10^{6}\right)\end{array}$} & \multicolumn{2}{c}{ EF column } & & \multicolumn{2}{c}{ Histone column } \\
\cline { 2 - 3 } \cline { 5 - 6 } & Before & After & & Before & After \\
\hline 0.5 & 16.6 & 1.2 & & - & - \\
0.2 & 16.3 & 1.3 & & 15.5 & 15.4 \\
0.1 & 17.7 & 1.5 & & 15.3 & 15.4 \\
0.05 & 8.0 & - & & 1.8 & 1.3 \\
0.01 & 1.7 & - & & - & - \\
\hline
\end{tabular}

TABLE 2

CHRONIC MS LYMPHOCYTES; EF AND MEASLES ANTIGENS: EF-BIO-GEL COLUMN

\begin{tabular}{cccccc}
\hline \multirow{2}{*}{$\begin{array}{c}\text { No. of cells } \\
\left(\times 10^{6}\right)\end{array}$} & \multicolumn{2}{c}{ Before EF column } & & \multicolumn{2}{c}{ After EF column } \\
\cline { 2 - 3 } \cline { 5 - 6 } & $E F$ & Measles & & $E F$ & Measles \\
\hline 3.3 & - & - & & 1.1 & - \\
0.2 & 15.6 & 10.5 & & - & 10.5 \\
0.1 & 15.5 & 8.4 & & - & 0.6 \\
0.05 & 6.3 & 2.2 & & - & - \\
0.025 & 1.5 & - & & - & - \\
\hline
\end{tabular}

2. Table 2 shows the effect of passing lymphocytes from a patient with chronic multiple sclerosis down an EF-Biogel column. It can be seen that, before the cells go down the column, $0.05 \mathrm{~m}$ are enough to give a positive result with EF and $0.1 \mathrm{~m}$ with measles. After the column, 
TABLE 3

MS LYMPHOCYTES; EF AND MEASLES ANTIGENS: EF-BIO-GEL COLUMN; NORMAL AND MEASLFS SERA

\begin{tabular}{|c|c|c|c|c|c|c|}
\hline \multirow{2}{*}{$\begin{array}{l}\text { No. of cells } \\
\quad\left(\times 10^{6}\right)\end{array}$} & \multicolumn{2}{|c|}{ Before column } & \multicolumn{2}{|c|}{ After column/normal serum } & \multicolumn{2}{|c|}{$\begin{array}{l}\text { After column/measles } \\
\text { serum }(1: 512)\end{array}$} \\
\hline & $E F$ & Measles & $E F$ & Measles & $E F$ & Measles \\
\hline $0 \cdot 2$ & $15 \cdot 1$ & $10 \cdot 3$ & $1 \cdot 5$ & $10 \cdot 4$ & $15 \cdot 4$ & $10 \cdot 2$ \\
\hline $0 \cdot 15$ & $15 \cdot 4$ & - & $1 \cdot 5$ & - & 15.0 & - \\
\hline $0 \cdot 1$ & $15 \cdot 0$ & $6 \cdot 5$ & $1 \cdot 3$ & $3 \cdot 8$ & 12.9 & $6 \cdot 8$ \\
\hline 0.05 & $5 \cdot 1$ & - & $1 \cdot 2$ & - & $3 \cdot 5$ & - \\
\hline
\end{tabular}

TABLE 4

MS LYMPHOCYTES; EF AND MEASLES ANTIGENS: EF-BIO-GEL COLUMNS; MUMPS AND NORMAL SERA

\begin{tabular}{|c|c|c|c|c|c|c|}
\hline \multirow{2}{*}{$\begin{array}{l}\text { No. of cells } \\
\left(\times 10^{6}\right)\end{array}$} & \multicolumn{2}{|c|}{ Before column } & \multicolumn{2}{|c|}{ After column/normal serum } & \multicolumn{2}{|c|}{ After column/mumps serum } \\
\hline & $E F$ & Measles & $E F$ & Measles & $E F$ & Measles \\
\hline 0.5 & - & - & 1.5 & - & 1.6 & - \\
\hline $0 \cdot 2$ & $14 \cdot 7$ & $10 \cdot 5$ & 1.7 & $10 \cdot 3$ & $1 \cdot 3$ & 10.0 \\
\hline $0 \cdot 1$ & 14.5 & $5 \cdot 3$ & - & $2 \cdot 2$ & $1 \cdot 3$ & $2 \cdot 3$ \\
\hline 0.05 & $6 \cdot 2$ & - & - & - & - & - \\
\hline
\end{tabular}

even $3 \cdot 3 \mathrm{~m}$ cells fail to give a positive result with $\mathrm{EF}$, and $0.1 \mathrm{~m}$ no longer gives a positive result with measles $(8 \cdot 4 \%$ has been reduced to $0.6 \%)$. Clearly removing cells which react with EF has also removed some cells which react with measles.

To test further the possible association between measles and EF, two Bio-Gel columns were loaded with EF. One was then washed through with normal serum (control) and the other with a measles serum (titre $1: 512$, haemagglutination-inhibition test). The object was to test whether measles serum would bind to the EF in the column and so diminish its capacity to retain EF sensitized cells. Table 3 shows this was indeed the case. Treating the Bio-Gel-EF column with measles (but not normal) serum abolished its ability to remove EF sensitized lymphocytes and also (at the $0 \cdot 1 \mathrm{~m}$ level) significantly reduced the retaining power of the column for lymphocytes sensitized to measles $(3.8 \%$ on normal column $; 6.8 \%$ on measles serum treated column). This experiment showed that measles serum of high titre could 'satisfy' the avidity of EF-BioGel for lymphocytes sensitized to measles.

3. A further experiment showed that mumps serum was unable to abolish the binding capacity of Bio-Gel-EF sensitive lymphocytes (Table 4).
There was no difference in the removal of either EF or measles sensitized by normal and mumps serum.

4. Since it is known that EF shares antigenic determinant with PPD (Field et al., 1963; Field et al., 1971), the ability of a PPD loaded Bio-Gel column to filter out PPD, EF and measles sensitized cells was tested (Table 5). It can be

TABLE 5

CHRONIC MS LYMPHOCYTES; EF, PPD AND MEASLES ANTIGENS: PPD-BIO-GEL COLUMN

\begin{tabular}{|c|c|c|c|c|c|c|}
\hline \multirow{2}{*}{$\begin{array}{l}\text { No. of cells } \\
\quad\left(\times 10^{6}\right)\end{array}$} & \multicolumn{3}{|c|}{ Before column } & \multicolumn{3}{|c|}{ After column } \\
\hline & $E F$ & $P P D$ & Measles & $E F$ & $P P D$ & Measles \\
\hline 1.0 & - & - & - & $1 \cdot 6$ & 1.4 & - \\
\hline 0.5 & $15 \cdot 4$ & $17 \cdot 7$ & - & - & - & - \\
\hline $0 \cdot 2$ & - & - & $10 \cdot 3$ & - & - & $10 \cdot 3$ \\
\hline $0 \cdot 1$ & - & - & $9 \cdot 3$ & - & - & $8 \cdot 5$ \\
\hline
\end{tabular}

seen that, while PPD filters out PPD and EF cells, it has no effect on measles (at $0.1 \mathrm{ml}$. reduction from $9.3 \%$ to $8.5 \%$-not significant). An EF loaded column filtered out some PPD cells. PPD would appear to be too far removed 
TABLE 6

MS LYMPHOCYTES; EF AND MEASLES ANTIGENS: MEASLES-BIO-GEL COLUMN

\begin{tabular}{cccccc}
\hline \multirow{2}{*}{$\begin{array}{c}\text { No. of cells } \\
\left(\times 10^{6}\right)\end{array}$} & \multicolumn{2}{c}{ Before column } & & \multicolumn{2}{c}{ After column } \\
\cline { 2 - 3 } \cline { 5 - 6 } & EF & Measles & & EF & Measles \\
\hline 0.2 & $14 \cdot 1$ & $9 \cdot 6$ & & $13 \cdot 7$ & $1 \cdot 3$ \\
$0 \cdot 15$ & $14 \cdot 1$ & - & & $12 \cdot 3$ & - \\
0.10 & $7 \cdot 6$ & - & & $5 \cdot 3$ & - \\
\hline
\end{tabular}

antigenically from measles to filter out cells sensitized to the latter.

5. MS lymphocytes when passed through a measles-Bio-Gel column show a large reduction in sensitivity to measles antigen, and a small but significant reduction in EF sensitivity (Table 6).
(Table 7). However, cells sensitized to PPD and thyroid were not reduced. Evidently, measles antigen(s) coupled to Bio-Gel is able to retain cells sensitized to measles and to a lesser degree EF but not to thyroid and PPD.

Measles control material-that is, the culture in which the measles virus was prepared-on the column led to no significant reduction in the number of either measles or EF sensitized cells coming through (Table 7).

MEASLES Table 8 shows the effect of passing lymphocytes from a child with measles through an EF-Bio-Gel column. There is a marked reduction in EF-sensitized cells and a significant reduction in those sensitized to measles antigen.

TABLE 7

STROKE LYMPHOCYTES; EF, MEASLES, PPD AND THYROID ANTIGENS: MEASLES-BIO-GEL AND CONTROL-BIO-GEL COLUMNS

\begin{tabular}{|c|c|c|c|c|c|c|c|c|c|c|}
\hline \multirow{2}{*}{$\begin{array}{l}\text { No. of cells } \\
\left(\times 10^{6}\right)\end{array}$} & \multicolumn{4}{|c|}{ Before column } & \multicolumn{4}{|c|}{ After measles column } & \multicolumn{2}{|c|}{ After control column } \\
\hline & $E F$ & Measles & $P P D$ & Thyroid & $E F$ & Measles & $P P D$ & Thyroid & $E F$ & Measles \\
\hline $3 \cdot 0$ & - & - & - & - & - & $3 \cdot 7$ & - & - & - & - \\
\hline 1.5 & - & - & - & - & - & $2 \cdot 3$ & - & - & - & - \\
\hline 0.2 & $15 \cdot 4$ & $11 \cdot 0$ & - & - & $15 \cdot 8$ & 1.8 & - & - & - & $10 \cdot 8$ \\
\hline $0 \cdot 1$ & $15 \cdot 5$ & 9.9 & $17 \cdot 4$ & $18 \cdot 7$ & $15 \cdot 2$ & - & $17 \cdot 6$ & $18 \cdot 7$ & $15 \cdot 5$ & $10 \cdot 2$ \\
\hline 0.075 & $14 \cdot 7$ & - & - & - & $11 \cdot 1$ & - & - & - & - & - \\
\hline 0.05 & $6 \cdot 2$ & $1 \cdot 3$ & - & $12 \cdot 3$ & $3 \cdot 4$ & - & - & $12 \cdot 5$ & 6.4 & - \\
\hline 0.025 & $1 \cdot 3$ & - & - & - & $1 \cdot 6$ & - & - & - & 1.6 & - \\
\hline
\end{tabular}

OTHER NEUROLOGICAL DISEASES As with MS, lymphocytes from a patient with stroke when passed through a measles-Bio-Gel column showed retention of significant numbers of lymphocytes sensitive to EF and measles

TABLE 8

MEASLES LYMPHOCYTES (SECOND DAY OF RASH); EF AND MEASLES ANTIGENS: EF-BIO-GEL COLUMN

\begin{tabular}{|c|c|c|c|c|}
\hline \multirow{2}{*}{$\begin{array}{l}\text { No. of cells } \\
\left(\times 10^{8}\right)\end{array}$} & \multicolumn{2}{|c|}{ Before column } & \multicolumn{2}{|c|}{ After column } \\
\hline & $E F$ & Measles & $E F$ & Measles \\
\hline $0 \cdot 2$ & $9 \cdot 0$ & - & $1 \cdot 3$ & - \\
\hline 0.15 & $8 \cdot 6$ & - & - & - \\
\hline $0 \cdot 1$ & $5 \cdot 1$ & $14 \cdot 3$ & - & $14 \cdot 4$ \\
\hline 0.075 & - & $13 \cdot 4$ & - & 10.8 \\
\hline 0.05 & 一 & $7 \cdot 0$ & - & $3 \cdot 3$ \\
\hline
\end{tabular}

\section{DISCUSSION}

Specific separation of cells on affinity columns for the study of differentiation in the immune response was described by Truffa-Bachi and Wofsy (1970). Their method was a development of the cell separation on antigen-coating columns previously described by Wigzell and Anderson (1969) and which they had used for the selective elimination of specifically sensitized cells by their retention on the column. The present work uses the very sensitive and highly discriminatory macrophage electrophoretic mobility (MEM) test for studying the sensitization of cells which come through an affinity column. This marriage of affinity chromatography with the MEM test has an obvious wide application in studying immunological cross- 
reactivity in general, and that between EF and cancer basic protein (Field et al., 1971) has recently been explored by this method by McDermott, Dickinson, and Caspary (unpublished).

The present results indicate that measles antigen is able to attract and hold not only blood lymphocytes which have specific reactivity to measles but also to a lesser degree those which are able to react with EF. Since this ability is counteracted by measles serum but not by the unrelated mumps serum, it appears specifically related to measles. Lymphocytes from patients with other neurological diseases-for example, stroke or syringomyelia-have similar sensitization to EF and measles confirming that there is nothing specific to multiple sclerosis in this respect (Caspary and Field, 1970).

The results offer direct evidence of antigenic determinant sharing between measles virus and EF. This study has also confirmed the suggestion that PPD is antigenically related to EF (Field et al., 1963; Field and Caspary, 1972) and indicates no significant determinant sharing between PPD and measles. The similarity in antigenic determinant(s) between measles and EF is great enough to account for the high antibody level to measles in multiple sclerosis patients (Field et al., 1972; Field, 1973). This is supported by the fact that there is a slightly higher level of measles antibody in neurological diseases other than MS (Caspary et al., 1969), especially if care is taken to study diseases with a degree of parenchymatous destruction comparable with that in MS. Few workers appear to have studied such controls which alone can offer evidence of specificity of change in multiple sclerosis.

The alternative explanation that there is a specific causal relation between measles virus and multiple sclerosis possibly as the result of infection persisting in 'slow' form has been maintained by Salmi et al. (1972). In support of their view, they point out that antibody to all three components of measles is raised in MS and regard it as unlikely that determinant sharing would involve them all. It would be of the greatest interest to apply the techniques described in this paper to the individual Norrby measles fractions and to study them also in other neurological diseases. However, the cellular affinity chroma- tography technique does not seek to dissect the measles component(s) responsible for crossreactivity (Norrby and Hammarskjöld, 1972) but merely establishes the actuality of the crossreaction and offers it as a basis for the observed measles-MS relationship. Additional evidence comes from the observation that during an attack of measles in children lymphocyte sensitization to EF rises (Field et al., 1972) and that immunization of experimental animals with measles leads to elevated lymphocyte sensitivity to EF (Field et al., 1973).

The authors are grateful to Dr. J. P. Dickinson for discussions relating to cell affinity chromatography; to Mr. A. Keith for the preparation of peritoneal macrophages; to colleagues in Newcastle University Hospitals for access to patients under their care, and to Dr. H. Madgwick for measles patients. The cytopherometers with which this work was carried out were provided by the N.E. Multiple Sclerosis Society and the Multiple Sclerosis Research Fund Ltd. Dr. J. R. McDermott holds a grant from the North East British Empire Cancer Campaign.

\section{REFERENCES}

Brody, J. A. (1972). Epidemiology of multiple sclerosis and a possible virus aetiology. Lancet, 2, 173-176.

Carnegie, P. R., Caspary, E. A., Dickinson, J. P., and Field, E. J. (1973). The macrophage electrophoretic migration (MEM) test for lymphocyte sensitization: a study of the kinetics. Clinical and Experimental Immunology, 14, 37-45.

Caspary, E. A., Chambers, M. E., and Field, E. J. (1969). Antibodies to measles antigen, control antigen, and monkey kidney antigen. Neurology (Minneap.), 19, 10381042.

Caspary, E. A., and Field, E. J. (1965). An encephalitogenic protein of human origin; some chemical and biological properties. Annals of the New York Academy of Sciences, 122, 182-198.

Caspary, E. A., and Field, E. J. (1970). Sensitization of blood lymphocytes to possible antigens in neurological disease. European Neurology, 4, 257-266.

Caspary, E. A., and Field, E. J. (1971). Specific lymphocyte sensitization in cancer: is there a common antigen in human malignant neoplasia? British Medical Journal, 2, 613-617.

Caspary, E. A., and Field, E. J. (1974). Lymphocyte sensitization to basic protein of brain in multiple sclerosis and other neurological diseases. Journal of Neurology, Neurosurgery, and Psychiatry (In press).

Coulson, A. S., and Chalmers, D. G. (1967). Response of human blood lymphocytes to tuberculin PPD in tissue culture. Immunology, 12, 417-429.

Field, E. J. (1973). Aetiology and pathogenesis of MS : role of viral infection and auto-immunity. Lancet, 1, 295-297.

Field, E. J., Caspary, E. A., and Ball, E. J. (1963). Some biological properties of a highly active encephalitogenic factor isolated from human brain. Lancet, 2, 11-13. 
Field, E. J., and Caspary, E. A. (1970). Lymphocyte sensitisation: an in-vitro test for cancer? Lancet, 2, 1337-1341.

Field E. J., and Caspary, E. A. (1971). Demonstration of sensitized lymphocytes in blood. Journal of Clinical Pathology, 24, 179-181.

Field, E. J., and Caspary, E. A. (1972). Lymphocyte sensitization in advanced malignant disease: a study of serum lymphocyte depressive factor. British Journal of Cancer, 26, 164-173.

Field, E. J., Caspary, E. A., and Carnegie, P. R. (1971). Lymphocyte sensitization to basic protein of brain in malignant neoplasia: experiments with serotonin and related compounds. Nature, 233, 284-286.

Field, E. J., Caspary, E. A., and Madgwick, H. (1972). Measles, multiple sclerosis, and encephalitogenic factor. Lancet, 2, 337.

Field, E. J., Caspary, E. A., Shenton, B. K., and Madgwick, H. (1973). Lymphocyte sensitization after exposure to measles and influenza. Journal of Neurological Sciences, 19, 179-187.
Hughes, D., and Caspary, E. A. (1970). Lymphocyte transformation in vitro measured by tritiated thymidine uptake. 1. Lymphocyte culture techniques. International Archives of Allergy, 37, 506-531.

Inman, J. K., and Dintzis, H. M. (1969). The derivitization of cross-linked polyacrylamide beads. Controlled introduction of functional groups for the preparation of special-purpose, biochemical adsorbents. Biochemistry, 8, 4074-4082.

Norrby, E., and Hammarskjöld, B. (1972). Structural components of measles virus. Microbios, 5, 17-29.

Salmi, A. A., Panelius, M., and Norrby, E. (1972). Multiple sclerosis and measles virus. Lancet, 2, 1088-1089.

Truffa-Bachi, P., and Wofsy, L. (1970). Specific separation of cells on affinity columns. Proceedings of the National Academy of Sciences, 66, 685-692.

Wigzell, H., and Andersson, B. (1969). Cell separation on antigen-coated columns. Elimination of high rate antibody-forming cells and immunological memory cells. Journal of Experimental Medicine, 129, 23-36. 